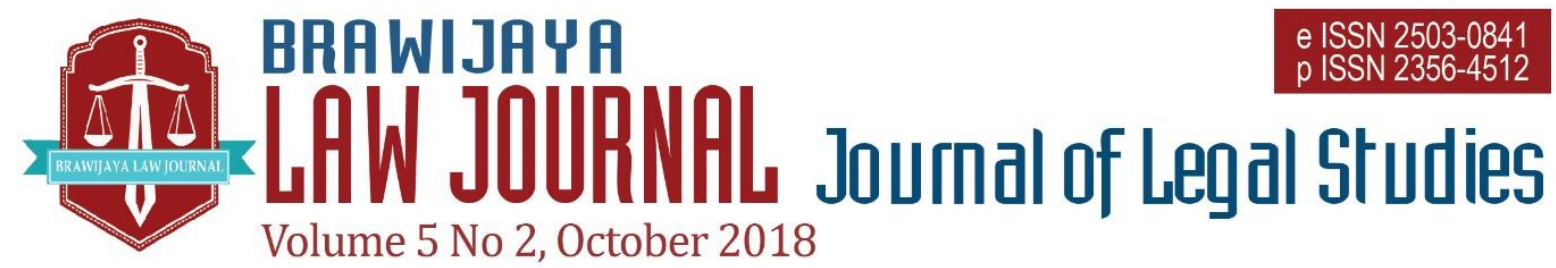

Nationally Accredited No. 32a/E/KPT/2017 Dated 26th April 2017

This work is licensed under a Creative Commons Attribution-NonCommercial 4.0 International License

\title{
Model of Prevention of Social Conflict which Multi Dimensions Based on Local Wisdom of Community Adat Dalihan Na Tolu
}

\author{
Anwar Sadat Harahap ${ }^{1}$, Ahmad Laut Hasibuan² \\ ${ }^{1}$ Universitas Muslim Nusantara (UMN) Al Washliyah Medan \\ Email: anwarsadathrp@umnaw.ac.id \\ ${ }^{2}$ Universitas Muslim Nusantara (UMN) Al Washliyah Medan \\ Email: ahmadlauthsb@yahoo.co.id
}

Submitted : 2017-10-10 | Accepted : 2018-10-17

\begin{abstract}
The main purpose of this research is to find a model of punishment in preventing social conflict on local wisdom of Dalihan na Tolu indigenous people. The questions posed in this research include the multi-dimension social conflict prevention model based on local wisdom of Indonesia, the deliberation stage of preventing such conflict and strategies adopted by local wisdom to resolve social conflict. The research further focuses its examination on local society that is Dalihan na Tolu indigenous people.

This research uses empirical juridical research method, which is departed from local wisdom norms, or known as adat laws and examines the application of such laws in society. This research proposes that the multi-dimensional model of social conflict prevention should be carried out using the rules contained in: Dalihan na Tolu custom, Sipaingot, Pastak ni Paradaton, Uhum dohot Patik, Hapantunon, Tutur dohot Poda, Marga, Martahi, Mangupa. While the system and strategies of negotiation to reach consencus in preventing multidimensional social conflict based on the following norms: Tahi Ungut-ungut, Tahi Dalihan na Tolu, Tahi Godang Parsahutaon and Tahi Godang Haruaya Mardomu Bulung. It is argued that the punishment model usually used by Batak community should be adopted both in preventing as well as resolving social conflict exists in society.
\end{abstract}

Keywords: $\quad$ prevention, social conflict, multi dimensions, community of adat dalihan na tolu

\section{INTRODUCTION}

It cannot be denied that in Indonesia there have been various social conflicts involving community groups with one another, such as civil war in Poso (1998 - 2001), Ambon (1999 - 2002), North Maluku (2000), Sampit conflict (2001), Idul Fitri Idul Fitri riot on November 2, 2006 in Air Bara village between indigenous people of Bangka and Air Sampik residents (majority of Javanese tribe) causing several houses of Air Sampik people burned, riot in Lampung Selatan Mesuji (2012) and others, riots broke out in the area of North Jakarta, precisely around 
Luar Batang, Penjaringan, Friday (4/11/2016) and others.

The majority of these problems arise, because they stem from other than less assertive, fair and beneficial legal regulatory materials on preventing social conflict that has been felt by the community so far, as well as indigenous peoples and their local wisdom has not been involved in the prevention of formal social conflict in the community. It is undeniable that the lives of indigenous peoples in Indonesia, such as the indigenous Batak community in North Sumatra, the Malay indigenous people in Riau, the Minangkabau indigenous people in West Sumatra, the indigenous Javanese in Yogyakarta and other indigenous peoples often face trials and challenges, such as bomb explosions in places of worship, inheritance conflicts, marriage conflicts, electoral conflicts, inter-youth disputes between different religions and tribes and other conflicts.

Most of these conflicts, can be overcome and prevented by indigenous peoples through customary law contained in their respective local wisdom, so as not to cause prolonged conflict in the midst of society. In the concept of local wisdom, it has been arranged in: 1) system and procedures for preventing and resolving social conflict, 2) mediation implementation process in the prevention of social conflict, 3) strategy by customary leaders in the prevention of social conflict, 4) solving social conflicts, and 6) the types of sanctions imposed on perpetrators who triggered social conflicts.

The above mentioned rules have been taught to all members of the indigenous community since childhood, so that the material is understood, respected and practiced in everyday life because it is in accordance with the legal ideals (rechtsidee) and legal feeling (rechtsgevool) of indigenous peoples. In addition, the existence of indigenous leaders in an indigenous community is still highly respected and respected, so that the order is executed and the prohibition is abandoned.

Prevention of social conflict wisely and wisely is not the finished goods that come for granted, but it is a social project that must be fostered and directed, so as to create social harmony, the nature of tolerance and the existence of mutual understanding and respect between communities with one another. ${ }^{1}$

Indonesia is one of many coutries that characterized with its cultural diversity. Each culture has its own wisdom in addressing life issues encountered, including wisdom in resolving conflicts. ${ }^{2}$ Tradition and local wisdom that still exist and apply in the community, has the potential to encourage the desire to live harmonious and peaceful. That's because the wisdom of local tradition basically teaches peace with each other, the environment, and God. ${ }^{3}$

According to Wasisto Raharjo Jati that there are five vital roles of local wisdom as media of religious conflict resolution, namely: 1) Local wisdom as a marker identity of a community. 2) Local wisdom itself provides a cohesive aspect of interreli-gious, cross-citizen, and belief elements. 3) Local wisdom as part of alternative conflict resolution is more to invite all parties to negotiate by taking advantage of emotional and cultural closeness. 4) Local wisdom serves to encourage the building of togetherness. 5)

1 Adawiyah Nasution, 'Penyelesaian Sengketa Pemilihan Kepala Daerah Berbasis Dalihan na Tolu', (2015) 1 (3) Jurnal Kalam Keadilan 96-99.

2 Ilyas, 'Kajian Penyelesaian Konflik antar Desa Berbasis Kearifan Lokal di Kabupaten Sigi,

Sulawesi Tengah', (2014) 6 (1) Jurnal Academica 1221.

3 Agus Sriyanto, 'Penyelesaian Konflik Berbasis Budaya Lokal', (2007) 5 (2) Jurnal Ibda 286-301. 
Local wisdom will change the mindset and mutual relationships of individuals and groups, by putting on top of the culture they possess. ${ }^{4}$ The potential of such a large nation must be managed properly and justly, because if it is allowed to go the way it is and according to individual taste, it is not impossible to cause prolonged conflict in the midst of society that can result in the emergence of acts of amok, clash and brawl can claim casualties. Based on the background presented above, it can be taken some formulation of the following research problems:

1. How is the multidimensional social conflict prevention model based on local wisdom on indigenous peoples in Indonesia?

2. How is the deliberation stage in preventing multidimensional social conflict based on local wisdom on indigenous people in Indonesia?

3. What is the strategy adopted by indigenous peoples in maintaining peaceful conditions as an effort to prevent multi-dimensional social conflicts based on local wisdom in Indonesia?

\section{LEGAL MATERIALS AND METHODS}

The research method used is empirical law research method, because empirical research is research about law living in society ${ }^{5}$, which applied or implemented by member of society. the problems examined concerning the actual practice undertaken by indigenous people Dalihan na Tolu in preventing the emergence of multidimensional social conflict.

4 Wasisto Raharjo Jati, 'Kearifan Lokal Sebagai Resolusi Konflik Keagamaan' (2013) 21 (2) Jurnal Walisongo 397.
While the approach used is to use anthropological approach (a science that studies the patterns of dispute and settlement in simple society, as well as people who are undergoing development and development process) and sociological jurisdiction (socio legal approach) or empirical juridical approach, society by studying social phenomenon in society which looks its legal aspect, considering the main issues studied and studied in this research are: 1) identification of customary law related to prevention of social conflict conducted by indigenous people Dalihan na Tolu, 2) effectiveness of adat institutions Guidelines on Tolerance related to the prevention of multi-dimensional social conflict perpetrated by the Dalihan na Tolu indigenous people.

\section{RESULT AND DISCUSSION}

\section{Prevention of Indigenous Peoples-Based}

Multi-Dimensional Social Conflict of Adat Dalihan na Tolu di Sumatera Utara

Indeed, each indigenous community in Indonesia has its own rules in preventing, reducing, resolving multi-dimensional social conflict in the midst of society, resulting in ethnicity, tranquility, and order in society. Thus will create unity and unity in the life of the nation and state as the main capital in achieving the ultimate goal in creating a prosperous just society prosperous as set forth in the purpose of the Unitary State of the Republic of Indonesia. Based on the above information, there are some indigenous peoples in Indonesia have the wisdom of loal in preventing, settling and settling conflict of multi-dimensional social conflict which one of them is the prevention of multi-dimensional social conflict through

5 Asri Wijayanti dan Lilik Sofyan Achmad, Strategi Penulisan Hukum, (Bandung: CV. Lubuk Agung, 2011), 97. 
indigenous local wisdom Dalihan na Tolu in North Sumatra.

Adat Dalihan na Tolu can be used as a means of preventing and resolving social conflicts in the midst of batak society. Because, through the customs Dalihan na Tolu each person has a kinship relationship with others who must fulfill their obligations and respect the rights of others. Kinship relationships are created because of the blood relations and marital relationships that are set in the Dalihan na Tolu kinship system. ${ }^{6}$

Gultom Rajamarpodang mentions Dalihan means "stove". Na means "yang", Tolu means "three". So Dalihan na Tolu means "three-legged stove", i.e three pieces of stone used as a foundation or pedestal for cooking. So the meaning of Dalihan na Tolu is a local community institution which is a unity of all people who have their own custom rules in regulating the various joints of life that can be used as a tool in overcoming various conflicts of rights and obligations. $^{7}$ The elements of Dalihan na Tolu referred to are: a) mora are all families that come from the in-laws. Mora is a group of relatives who give boru (daughter) to be wife, b) Boru's son is all family of the son-inlaw. This means that the family comes from the person who took Boru (the daughter) of a person without exception. Usually, the Boru Anak family has a clan that varies depending on the surname of the son-in-law or the one who takes one's daughter. Even sometimes children boru can be different religions with moranya, c) Kahanggi is all families or descendants who have a blood relationship from the father. ${ }^{8}$

6 Djamaluddin Siregar, 'Peranan Adat Dalihan na Tolu dalam Pelaksanaan Kerukunan Umat Beragama pada Masyarakat Batak' (2014) 3 (6) Jurnal Kultura 86.

7 Syahmerdan Lubis Gelar Baginda Raja Muda, Adat Hangoluan Mandailing Tapanuli Selatan, a. The three elements of indigenous peoples Dalihan na Tolu above synergize in the elimination of mitigation and settlement of multidimensional social conflict in society by referring to the existing rules.

b. The multidimensional rule of social conflict prevention through the customary philosophy of Dalihan na Tolu: "Somba mar Mora (honor, obedience and obedience to Mora), Elek mar Anak Boru (seducing and taking the heart of Anak Boru), Manat-mar marahahah (mutual respect and appreciate Kahanggi) ". Based on the rules contained in the philosophy that Mora has an obligation in protecting, protecting and providing security for the Borneo. Mora is obliged to perform his duties as a guardian, protector, and safety giver for his Borneo, both living close to him and living with him. Mora in Dalihan na Tolu custom is distilled with haruaya (banyan tree) which has leaf that shade again wide, strong tree again big, strong root and life durable. Shady banyan trees serve as shelter from the hot sun, shelter from rain water, shelter from strong winds, rest areas not only for humans, but also for animals. Such is the parable of the duty and responsibility of a mora to his son, he must be able to provide protection, security and peace for those who are nearby.

Based on the rules contained in the philosophy that Boru Children have an obligation in the prevention, settlement

(Medan: CV. Abdi Utama, 2013), 175.

8 Anwar Sadat Harahap, 'Keberadaan Dalihan na Tolu di Tengah Kehidupan Beragama' (2011) 2 (8) Jurnal Kalam Keadilan 205. 
and settlement of social conflict based on some of the following rules: 1) Nagogo Manjujung (Boru's son is always empowered to uphold the pride and dignity of Moranya); 2) Na Juljul tu Jolo (Son Boru always in front of paved the way, eliminating all obstacles in the way that mora will pass); 3) Na Torjak tu Pudi (Son Boru as the support and support from the back of the mora.) When the mora is in trouble, then Boru's son immediately plays a role in the back to help, in order to achieve Moranya's goals and succeed); 4) Tangkot di na Landit (Boru's child can serve as a barrel on every slippery road as a support for the body to avoid falling); 5) Sulu-sulu di na Golap (Anak Boru as a lamp in the dark for Moranya) If Mora is in distress as if in darkness, losing direction, then the Son of Boru can serve as a lamp so as not to lose direction; 6) Si Tamba na Hurang (Anak Boru can cover any shortcomings of Moranya); 7) Horus na Lobi (Anak Boru also has the right to take advantage of a well-organized event); 8) Manyoging Piri (If there is an offense to the mora, then the Son of Boru will not dare to scold his moranya but he will keep the honor of the manga); 9) Hapinis Hapinis (keys, bars or fences that keep people from entering a protected place means that Anak Boru has the function of guarding Moranya so that he will not be disturbed by others); 10) Tongan Tonga-tonga (Boru's son serves as a unifier and interpreter for all Moranya) Boru's son should not take sides, he must prove his affection to all Moranya without favoritism).

While Kahanggi has an obligation to maintain each other's feelings and treat Kahanggi as self and family, due to the same blood and clan relationship.
Dalihan na Tolu symbolizes three groups of indigenous peoples who work together to solve all matters. All loads are shared. This is a symbol of mutual cooperation, togetherness, rights and duties, tolerance, compassion, so kinship remains well preserved.

The strong sense of kinship and fraternity that the natural nature of Dalihan na Tolu community makes one of the factors of creating brotherhood and intimacy in the midst of society. The reason, if there is a dispute between two or more people, although different religions, usually will be resolved quickly due to a familial relationship between them according to the concept of Dalihan na Tolu. How could there be enmity if the opposite of his dispute is his kahangginya, his son or his moranya. Mora would not have the heart to be hostile enough to hurt his sons. Because, he is part of his son-in-law family.

c. The multidimensional rule of social conflict prevention through Sipaingot, meaning the advice of the parent or harajaon party and the hatobangan whose emphasis is on the giving of warnings about: a) works which may or may not be done, b) and should not be spoken, d) attitude that may and may not be allowed. The use of sipaingot in daily life in Indigenous people Dalihan na Tolu can be seen at table 1 .

Table 1. Use of sipaingot in daily life in Indigenous people Dalihan na Tolu

\begin{tabular}{llrr}
\hline No & $\begin{array}{c}\text { Use sipaingot in } \\
\text { Adat Dalihan }\end{array}$ & Amount & $\%$ \\
& na Tolu society & & \\
\hline 1 & Very Often Used & 159 & 78.8 \\
2 & Often Used & 43 & 21.2 \\
3 & Rarely Used & 0 & 0 \\
4 & No Longer Used & 0 & 0 \\
\hline \multicolumn{4}{c}{ Amount } \\
\hline
\end{tabular}


d. The multidimensional rule of social conflict prevention through Paradaches, which means that rules and regulations are permissible and should not be done in the midst of society in various spheres of life. All rules that limit the behavior of a person in society is included in the category of pastak $n i$ paradaton as:

1. "Olat ni dapur do anak boru, angkon in tonga do mora, tu jae tu julu do kahanggi", meaning: position and place of a child boru (family from the son-in-law) in the activities of siriaon (activities that are joy) customs that are silulutons (customary activities that are claimed) are in the kitchen. While the position of the mora (the family of the in-laws) in every custom activity that is both siriaon and siluluton is located in the position in the living room or the main room, because he is the party pangidoan poda (the party who asked for advice). Then kahanggai (blood family) freely occupy the face, back, outside the house;

2. "Mora do Bona Bulu", meaning: It is the mora who always plant bamboo trees in a village;

3. "Manyurduon burangir do mula ni pokat dohot pasampeon tona", meaning: every start of the deliberation and also convey an invitation in the execution of a party, must be preceded by thrusting burangir (betel leaf) first in front of harajaon (royal).

e. Multi-dimension of social conflict prevention rule through Uhum dohot Patik. Uhum means law and Patik means benchmark or provision. Uhum is a rule accompanied by sanctions, while Patik is a provision that sometimes not accompanied by sanctions. In Uhum and Patik have been arranged about the various joints of life that became the guidance of indigenous peoples in acting, saying, acting, including in maintaining security and public order;

f. The multidimensional rule of social conflict prevention through Hapantunon means the various rhymes or proverbs of the Batak community that lead to the prohibition of harming others, the prohibition of libel, the hostile prohibition. Instead advocate for the exercise of harmony and togetherness, co-operation, helphelping and other good deeds. Hapantunon leads to the prohibition of harming others, the prohibition of libel, hostile bans;

g. A multi-dimensional rule of social conflict prevention through Tutur. Speech, meaning the calling of intimacy to others in accordance with the bonds of blood, dairy bond or marital bond. While Poda means advice or advice that aims to lead to the right path and avoid a misguided path.

Each Tutur contains moral values, ethical values, and character of very high spiritual values, so that by applying the meaning of each Tutur, undoubtedly can maintain harmony, harmony and intimacy in the community. So that the various seeds of conflict will be resolved properly, without causing new conflicts or prolonged conflicts. 
Table 2. Type of speech on Angkola Batak society and ethics contained in it

\begin{tabular}{|c|c|c|c|c|}
\hline $\begin{array}{c}\text { Kind of } \\
\text { Family } \\
\text { Relationship }\end{array}$ & Kind of Tutur & $\begin{array}{l}\text { Values of ethics, } \\
\text { morals and morals } \\
\text { vertically from the } \\
\text { bottom up }\end{array}$ & $\begin{array}{c}\text { Values of ethics, } \\
\text { morals and morals } \\
\text { vertically from top } \\
\text { to bottom }\end{array}$ & $\begin{array}{l}\text { The value of } \\
\text { ethics, morals } \\
\text { and morals } \\
\text { horizontally }\end{array}$ \\
\hline Upward line & $\begin{array}{l}\text { 1. Ompung (grand } \\
\text { parents) } \\
\text { 2. Aya (Father) } \\
\text { 3. Uma (Modher) } \\
\text { 4. Amang Boru (The } \\
\text { father's wife) } \\
\text { 5. Ambou (Sister / } \\
\text { Paternal Wife of the } \\
\text { Wife) } \\
\text { 6. Tulang (Sister / } \\
\text { Paternal Wife of the } \\
\text { Wife) } \\
\text { 7. Nantulang (The } \\
\text { mother-in-law of the } \\
\text { mother / sister of the } \\
\text { mother) }\end{array}$ & $\begin{array}{l}\text { 1. Honoring } \\
\text { degree; } \\
\text { 2. Keeping his } \\
\text { honor; } \\
\text { 3. Love it; } \\
\text { 4. Comply with } \\
\text { his orders; } \\
\text { 5. Make it happy; } \\
\text { 6. Caring for it; } \\
\text { 7. Help him; } \\
\text { 8. 8. Lifting. }\end{array}$ & $\begin{array}{l}\text { 1. Love him; } \\
\text { 2. Providing } \\
\text { motivation, } \\
\text { encouragement and } \\
\text { support; } \\
\text { 3. Encourage and } \\
\text { support it; } \\
\text { 4. Appreciate his } \\
\text { achievements and } \\
\text { credibility; } \\
\text { 5. Watching him; } \\
\text { 6. Provide evaluation } \\
\text { and constructive } \\
\text { criticism; } \\
\text { 7. Facilitatinga. }\end{array}$ & $\begin{array}{l}\text { Mutual respect } \\
\text { and appreciation }\end{array}$ \\
\hline $\begin{array}{l}\text { Downward } \\
\text { line }\end{array}$ & $\begin{array}{l}\text { 1. Amang (suns) } \\
\text { 2. Boru (Anak } \\
\text { Perempuan) } \\
\text { 3. Parumaen (Menantu } \\
\text { Perempuan) } \\
\text { 4. Babere (Menantu } \\
\text { Laki-laki) } \\
\text { 5. Pahoppu (Cucu) }\end{array}$ & $\begin{array}{l}\text { 1. Respect; } \\
\text { 2. Keeping his } \\
\text { honor; } \\
\text { 3. Serve him; } \\
\text { 4. Comply with his } \\
\text { orders; } \\
\text { 5. Make it happy; } \\
\text { 6. Caring for him; } \\
\text { 7. Help him; } \\
\text { 8. Raised its degree. }\end{array}$ & $\begin{array}{l}\text { 1. Respect; } \\
\text { 2. Keeping his honor; } \\
\text { 3. Serve him; } \\
\text { 4. Comply with his } \\
\text { orders; } \\
\text { 5. Make it happy; } \\
\text { 6. Caring for him; } \\
\text { 7. Help him; } \\
\text { 8. Raised its degree. }\end{array}$ & $\begin{array}{l}\text { Mutual respect } \\
\text { and appreciation }\end{array}$ \\
\hline $\begin{array}{l}\text { Lineage } \\
\text { sideways }\end{array}$ & $\begin{array}{l}\text { 1. Uak Abang / } \\
\text { Dad's sister) } \\
\text { 2. Uda (Dad's Father's } \\
\text { Brother) } \\
\text { 3. Nanguda (Adek } \\
\text { Ayah's Wife) } \\
\text { 4. Abang (Abang) } \\
\text { 5. Angkang (brother) }\end{array}$ & & & $\begin{array}{l}\text { 1. Mutual respect } \\
\text { and } \\
\text { appreciation; } \\
\text { 2. Loving each } \\
\text { other; } \\
\text { 3. Help each } \\
\text { other; } \\
\text { 4. Mutual support }\end{array}$ \\
\hline $\begin{array}{l}\text { Relationship } \\
\text { kinship } \\
\text { because of } \\
\text { marriage }\end{array}$ & $\begin{array}{l}\text { 1. Husband } \\
\text { 2. Wife }\end{array}$ & & & $\begin{array}{l}\text { 1. Mutual respect } \\
\text { and } \\
\text { appreciation; } \\
\text { 2. Love each } \\
\text { other; } \\
\text { 3. Help each } \\
\text { other; } \\
\text { 4. Mutual support }\end{array}$ \\
\hline
\end{tabular}

All moral values, ethics and morals contained in the above Speech become the main values that serve to strengthen the relationship of brotherhood and avoid disputes and hostilities.

$\mathrm{h}$. The multidimensional rule of social conflict prevention through Marga, meaning the grouping of Angkola Batak society which aims to regulate marriage, so that the offspring can improve. In order to avoid the occurrence of inbreeding marriages, they make a community of clans in the clan. The main purpose of the formation of this clan by the ancestors first is in addition to knowing one's offspring, is also intended to avoid the occurrence of marriage with people semarga; 


\section{Deliberation System in Prevention of} Social Conflict on Society Adat Dalihan na Tolu

Deliberation in preventing and resolving multi-dimensional social conflicts on indigenous people Dalihan na Tolu was conducted with several levels of deliberation in accordance with the status of the people present in a deliberation.

First level is Tahi Ungut-ungut (family deliberation). Tahi Ungut-ungut is also named with the term Martahi Tot or Tahi Unung-unung ni Sibahue. In this level deliberation is carried out between husband and wife. If the problem cannot be solved between husband and wife, then deliberation is attended by parents and siblings of the husband, if the problem comes from the husband. And if the problem comes from the wife, then the deliberation will be attended by the parents and siblings of the wife. And if the problem also has not been completed in this way, then the deliberation continues with the presence of parents and siblings of both parties simultaneously;

The second is Tahi Dalihan na Tolu or also known as Martahi Sabagas. At this level, deliberations are held between Mora, Kahanggi, and Anak Boru. This deliberation is held, if the dispute discussed in the first stage has not been completed, then the settlement is resumed in the deliberation in this second level. Generally the social conflicts discussed in this stage can be resolved well.

The third is Tahi Godang Parsahutaon (Great Deliberation in a township). The deliberations at this level were attended by other than the husband / wife, the representatives of the Dalihan na Tolu group, also attended by: Raja Panusunan Bulung (Raja in a settlement / territory), traditional figures, Hatobangon (ancestral men), Banana Rahut Anak Boru from Anak Boru),
Ompu ni Kotuk (Anak Boru in the village), Rich People (people who are adat experts);

Then the fourth level is Tahi Godang Haruaya Mardomu Bulung (Major deliberation between village or Luat bordering directly). The deliberations at this level were attended by non-spouses, representatives of the Dalihan na Tolu group, traditional leaders, Harajaon, Hatobangon, Banana of the Mute, the Rich, also attended by Raja Panusunan Bulung (Raja who came from a work place or where the dispute happens) and King Torbing Block (Raja who comes from another area / neighbor adjacent to the area where the work place or where the dispute occurred).

The four levels of deliberation above are tiered and hierarchical levels that must be passed sequentially. If there is social conflict in the community, first settled in the first level of deliberation. If the deliberations within this level are considered to be over, then no further deliberations will be resumed in the next stage. But if the conflict has not been resolved in the deliberations at the first level, then proceed to the second level of deliberation, and if the conflict cannot be resolved, then proceed to deliberation in the fourth level.

Table 3. Respondents' answers about the perception of the community towards the settlement of multi-dimensional social conflict from the results of deliberations held by the community adat Dalihan na Tolu

\begin{tabular}{cccc}
\hline $\begin{array}{c}\text { No } \\
\text { Respondents } \\
\text { Answers }\end{array}$ & Amount & $(\boldsymbol{\%})$ \\
\hline 1 & Veri grateful & 179 & 88.7 \\
2 & Ordinary & 23 & 11.3 \\
3 & Less acceptable & 0 & 0 \\
4 & Not Acceptable & 0 & 0 \\
\hline \multicolumn{2}{c}{ Amount } & 202 & 100 \\
\hline
\end{tabular}

Source: Primary Data 2015

Usually the results of decisions issued based on the results of the indigenous 
community consultation Dalihan na Toluk with the results of decisions issued by the Religious Court or District Court is very different in the midst of society. More details can be seen in the table 3 .

The table 3 show that $88.7 \%$ of respondents answered that the results of the decisions issued based on the results of the deliberations of the indigenous people of Dalihan na Tolu were very acceptable, and $11.3 \%$ answered normal and $0 \%$ answered unacceptably and $0 \%$ of the samples answered no beer. Therefore, the majority of the public considers that the results of decisions issued based on the results of the deliberations are very acceptable because they are considered more bringing justice and truth.

It cannot be denied that occasional occassional social conflicts occur among indigenous peoples, such as marriage-related conflicts, customary land sale, land boundary determination and so on. Generally all types of conflicts within indigenous peoples are resolved through indigenous deliberations. Even if the social conflicts are resolved through the court of justice the numbers are small. More details can be seen in the table 4 .

Table 4. How to resolve social conflict in society adat Dalihan na Tolu

\begin{tabular}{|c|c|c|c|}
\hline No & $\begin{array}{l}\text { Respondents' } \\
\text { Answers }\end{array}$ & Amount & $(\%)$ \\
\hline 1 & $\begin{array}{l}\text { through } \\
\text { customary } \\
\text { deliberations }\end{array}$ & 170 & 84.2 \\
\hline 2 & $\begin{array}{l}\text { Through the } \\
\text { judiciary in the } \\
\text { district court }\end{array}$ & 12 & 5.9 \\
\hline \multirow[t]{2}{*}{3} & $\begin{array}{l}\text { Through the trial } \\
\text { with the village } \\
\text { apparatus }\end{array}$ & 20 & 9.9 \\
\hline & & 120 & 100 \\
\hline
\end{tabular}

Table 4 exposure indicates that $84.2 \%$ of the sample responded that the social conflicts occurring within indigenous peoples were resolved through deliberation, $5.9 \%$ of the respondents answered were resolved through the courts in the district courts and $9.9 \%$ of the respondents answered were resolved through the village apparatus trial. These data indicate that generally the social conflicts occurring within indigenous Batak communities, resolved through customary deliberations.

The indigenous people of Dalihan $n a$ Tolu consider the decision to be born based on the results of the deliberation is to bring more justice, benefit and legal certainty. This condition is influenced by several things. The first is settlement of social conflict through deliberation is a long-termed settlement since ancient times; Second is the parties acting as breakers are respected and respected because they are descended from kings, adat leaders and representatives of indigenous families of Dalihan na Tolu; The Third is settlement of social conflicts based on deliberations has very strict requirements and procedures, so the root of the problem can be known. Only then shall a fair decision be made to the parties witnessed by the whole community; and the Fourth is the sanctions imposed on the results of the deliberations are sanctions that are moral by not excluding civil sanctions such as compensation, fines, deprivation of rights, termination of marriage and other relationships. Every deliberation in the settlement of social conflicts and prejudices which pertain to new social, social and cultural life is said to be perfect if it has been supported by the three kinship groups, like three stoves (dalihan) that support one another.

Dedi Kurniawan and Abdul Syani mention that conflict resolution can be done by rectifying the disputes that occur. Good communication is the most important way to make conflicts that can be easily resolved and 
solved. ${ }^{9}$

Abraham Nurcahyo argues that the cultural approach model emphasizes more socially oriented social activities by engaging both conflicting sides. Implementation of conflict transformation model by using socio-cultural approach can be done through important events such as commemorations of independence day, youth oath or the day of heroes. $^{10}$

Agus Sriyanto believes that there are several terms in conflict resolution, namely (1) conflict prevention, (2) conflict resolution, (3) conflict management, (4) conflict resolution, (5) conflict transformation. Social conflicts can also arise because they are influenced by legal discrimination. In this case Zaka Firma Aditya argued that as a state organizer, the government often issued discriminatory regulations and policies and tended to cause intolerance to religious and minority faiths, especially to indigenous peoples. $^{11}$

Strategy of Indigenous Leaders in the Prevention of Multi-Dimensional Community-Based Social Conflict Adat Dalihan na Tolu in Nort Sumatera

Long before the emergence of a multidimensional social conflict to the surface, usually adat leaders have applied various strategies that are very telling and very powerful in reducing the emergence of social conflict itse lf. The various strategies in preventing the emergence of social conflicts that have been applied so far can be seen in the table 5 .

Table 5. Strategy applied by customary leaders in preventing social conflict in the community adat

Dalihan na Tolu

\begin{tabular}{|c|c|c|c|}
\hline No & Respondents' Answers & Amount & $(\%)$ \\
\hline 1 & $\begin{array}{l}\text { Give examples of exemplary in practice some principles adat Dalihan na } \\
\text { Tolu as: } \\
\text { a. Marsihaholongan (love each other); } \\
\text { b. Marsipagodakkon (raising each other up); } \\
\text { c. Marsihapadean (to do good with each other); } \\
\text { d. Marsibegean (listening to each other), } \\
\text { e. Marsilehenan (give each other); } \\
\text { f. Marsipagabean (mutual happy), } \\
\text { g. Marsipangiboan (give each other mercy); } \\
\text { h. Marsitolongan (helping each other), } \\
\text { i. Marsilehenan (give each other); } \\
\text { j. Marsihargaan (mutual respect); } \\
\text { k. Marsipaingotan (remind each other). }\end{array}$ & 56 & 27.7 \\
\hline 2 & Giving tasks to all community groups in maintaining security and order & 23 & 11.3 \\
\hline 3 & Involves all community groups in the execution of siriaon and siluluton & 32 & 15.8 \\
\hline 4 & $\begin{array}{l}\text { Practice philosophy somba mar mora, elek mar anak boru, manat-manat mar } \\
\text { kahanggi }\end{array}$ & 74 & 36.6 \\
\hline 5 & Involving young people in every indigenous activity of siriaon and siluluton & 12 & 7.4 \\
\hline 6 & $\begin{array}{l}\text { Encourage children to see and pay attention to all customary activities in the } \\
\text { community }\end{array}$ & 3 & 1.5 \\
\hline 7 & Always give advice on keeping unity and unity in every customary practice & 2 & 0.9 \\
\hline & Amount & 202 & 100 \\
\hline
\end{tabular}

Source: Primary Data 2016

9 Dedi Kurniawan dan Abdul Syani, 'Faktor Penyebab, Dampak dan Strategi Penyelesaian Konflik Antar Warga di Kecamatan Way Panji Kabupaten Lampung Selatan' (2013) 15 (1) Jurnal Sosiologi 7

10 Abraham Nurcahyo, Soebijantoro, Yudi Hartono, 'Model Rekonsiliasi Kultural untuk Mengatasi
Konflik Sosial antar Perguruan Silat di Madiun' (2014) 6 (2) Jurnal Studi Sosial 71

11 Zaka Firma Aditya, 'State Liability for Violation of Constitutional Rights Against Indigenous People in Freedom of Religion and Belief', (2017) 3 (1) Brawijaya Law Journal 29. 
Table 5 shows that there are 27.7 reply that gives exemplary example in applying some customary principles of Dalihan na Tolu, there are $11.3 \%$ of the sample replied that by assigning tasks to all community groups in maintaining security and order, there are $36.6 \%$ of samples answered by practicing the philosophy of somba mar mora, elek mar anak boru, manatman mar kahanggi is a strategy to prevent conflict in the midst of batak society. Thereafter $7.4 \%$ of the sample responded that by involving young people in each of the indigenous activities of siriaon and siluluton, $1.5 \%$ of the sample responded that by involving all community groups in each of the implementation of the siriaon and siluluton as part of the strategy in preventing conflicts within indigenous people batak. And $0.9 \%$ of the sample answered that by Always advising on keeping unity and unity in every customary practice. All of these strategies are used to instill and prevent conflict in the community.

Based on the table 5, there are 7 (seven) strategies implemented by indigenous people Dalihan na Tolu in preventing, settling and resolving disputes that arise in multi-dimensional social conflict in the midst of society, so that all members of the community start from the young to the parents can be prevented from actions that can lead to conflicts within the community. The customary law of Dalihan na Tolu not only provides a rule of how the process and procedure of solving social conflict only, but more than that also teaches how to avoid the members of society to not fall and fall into a conflict. Therefore, many things must be passed and taken into account in running the life of society as stipulated in the custom of Dalihan na Tolu itself. The rules of the customary institutions of Dalihan na Tolu are non-scriptum or non justifiably, but they have been set about the procedure for resolving social conflicts. In fact, the types of social conflicts that occur in the middle of society are generally the same among the regions with other regions, only different names and models of resolution.

Table 6. Data comparing the use of local wisdom with the District Court in resolving multi-dimensional social conflicts in Indigenous communities Dalihan na Tolu Year 2014 - 2016.

\begin{tabular}{|c|c|c|c|c|c|c|c|}
\hline \multirow[t]{3}{*}{ No } & \multirow[t]{3}{*}{ Type of Social Conflict } & \multicolumn{6}{|c|}{ Dispute Resolution } \\
\hline & & \multicolumn{2}{|l|}{2014} & \multicolumn{2}{|l|}{2015} & \multicolumn{2}{|l|}{2016} \\
\hline & & $\begin{array}{l}\text { Adat } \\
\text { Dalihan } \\
\text { na Tolu }\end{array}$ & $\begin{array}{l}\mathrm{PN} \\
/ \mathrm{PA}\end{array}$ & $\begin{array}{l}\text { Adat } \\
\text { Dalihan } \\
\text { na Tolu }\end{array}$ & P.N/PA & $\begin{array}{l}\text { Adat } \\
\text { Dalihan } \\
\text { na Tolu }\end{array}$ & P.N/PA \\
\hline \multirow[t]{10}{*}{1} & Conflict About Marriage & & & & & & \\
\hline & a. Divorce & 4 & 3 & 2 & 1 & 5 & 2 \\
\hline & b. Kawin Sumbang & - & - & 2 & - & 4 & - \\
\hline & c. Kawin Sopar & 3 & - & 1 & - & 5 & - \\
\hline & d. Kawin Mangalakkai & 7 & - & 4 & - & 2 & - \\
\hline & e. Kawin na Ditinggalkon & 3 & - & 2 & - & - & - \\
\hline & f. Kawin yang ditarik Paksa & 1 & - & 3 & - & 2 & - \\
\hline & g. Kawin Marlojong & 6 & - & 3 & - & 9 & - \\
\hline & h. Kawin Mangirit & - & - & 1 & - & - & - \\
\hline & i. Kawin Maninian & - & - & - & - & - & - \\
\hline \multirow[t]{4}{*}{2} & Ulayat Land Conflict & & & & & & \\
\hline & c. Ransacked Ulayat Land & 4 & - & 2 & - & - & - \\
\hline & d. d. Sale of Ulayat Land & 3 & - & 1 & - & - & - \\
\hline & $\begin{array}{l}\text { e. PUnilateral Land } \\
\text { Management }\end{array}$ & 1 & 2 & 2 & 3 & 1 & - \\
\hline
\end{tabular}




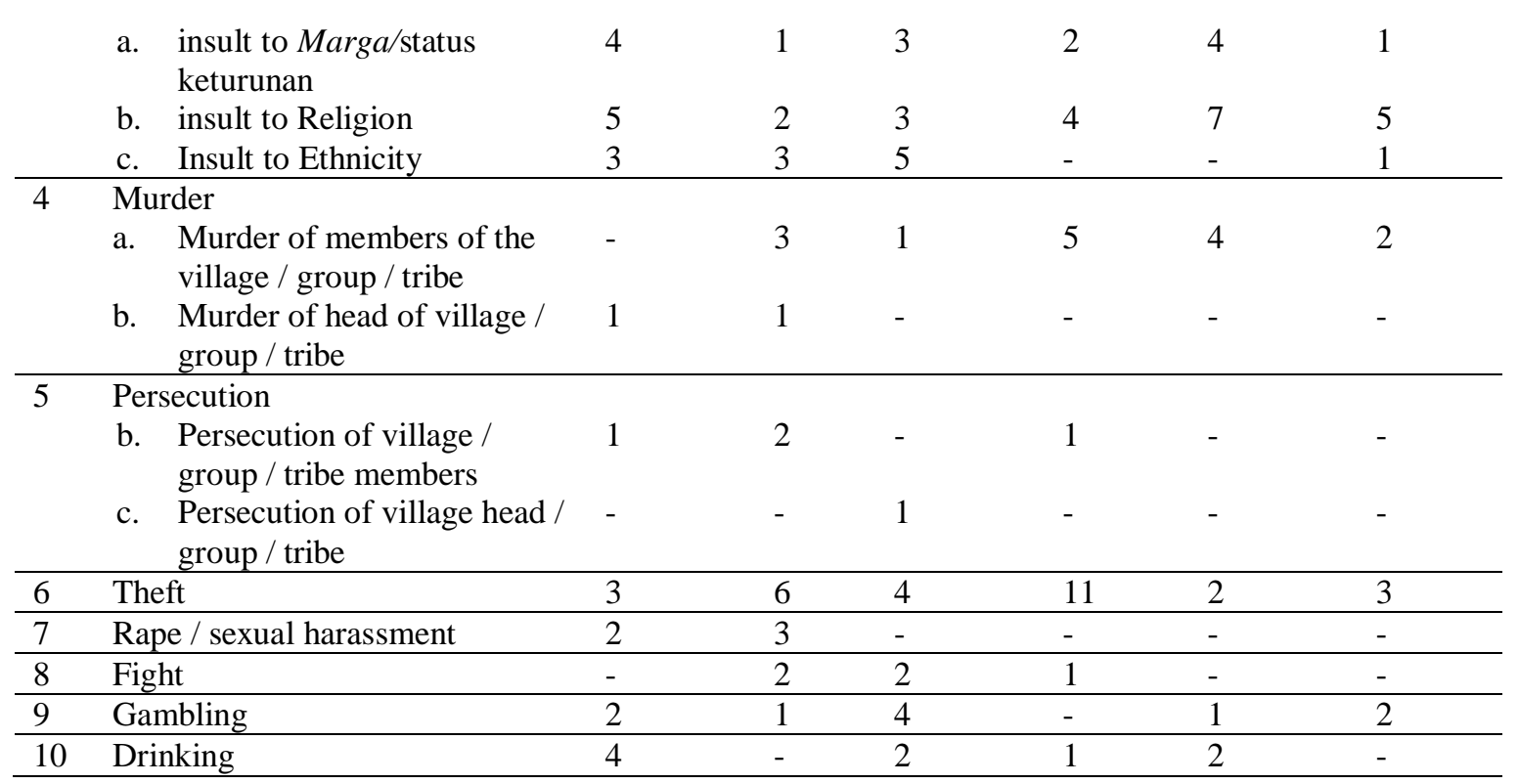

Source: Customary Institutions and Several District Courts in North Sumatra 2014-2016.

Yurika Dibba Destari Deiredja argues that indigenous and tribal peoples prefer the settlement of disputes through deliberations in order to bring peace to society. The use of musyawarah does not mean denying the process of dispute resolution through customary court. ${ }^{12}$

According to Wasisto Raharjo Jati that there are five vital roles of local wisdom as media of religious conflict resolution, namely: 1) Local wisdom as a marker identity of a community. 2) Local wisdom itself provides a cohesive aspect of interreligious, cross-citizen, and belief elements. 3) Local wisdom as part of alternative conflict resolution is more to invite all parties to negotiate by taking advantage of emotional and cultural closeness. 4) Local wisdom serves to encourage the building of togetherness. 5) Local wisdom will change the mindset and mutual relationships of individuals and groups, by putting on top of the culture they possess.

Siti Hamidah argues that the sociolo-

12 Yurika Dibba Destari Deiredja, Rizky Gelar Pangestu, Hassanain Haykal Haykal, 'Pengembangan Metode Alternatif Penyelesaian Sengketa Bisnis Berdasarkan Kearifan Lokal Melalui Jalur Mediasi' (2013) 2 (2) Zenit 142. gical condition of the majority affects the formulation of law and constributes to the law which includes the issue on constitutional law. ${ }^{13}$

\section{CONCLUSIONS AND SUGGESTIONS Conclusions}

a. Completion of Multi-Dimensional Social-Based Social Conflict Daihan na Tolu in the following ways: a. Dalihan na Tolu, b.Sipaingot, c, Pastak ni Paradaton, d. Uhum dohot Patik, e. Hapantunon, f. Tutur dohot Poda, g. Marga, h. Dafa nu Tolu, i. Martahi, j. Mangupa. All of these models are used by the indigenous people of Dalihan na Tolu in resolving multi-dimensional social conflict, so that the potential for conflict can be mitigated and if a conflict has been resolved properly, wisely and wisely;

b. The system of deliberation in preventing, reducing and resolving multi-dimensional social conflict as

13 Siti Hamidah, 'The Analysis of Islamic Economy in The Constitution of indonesia' (2017) 4 (1) Brawijaya Law Journal 59. 
follows: 1) Tah-Ungut-ungut (family deliberation), 2) Tahi Dalihan na Tolu. Deliberation conducted between Mora, Kahanggi, and Anak Boru, 3) Tahi Godang Parsahutaon (Major deliberation in a village), 4) Tahi Godang Haruaya Mardomu Bulung (Major deliberation between village or Luat bordering directly);

c. The strategy of indigenous leaders in preventing multi-dimensional social conflicts are as follows: 1) Provide examples of exemplary principles in practice some customary principles Dalihan na Tolu, 2) Provide tasks to all community groups in maintaining security and order, 3) Involve all community groups in every implementation of siriaon and siluluton, 4) practice the philosophy of somba mar mora, elek mar anak boru, manat-mar mar kahanggi, 5) advise children to see and pay attention to all customary activities in society, 6) always give advice about keeping unity and unity in every customary practice.

\section{Suggestions}

It is advisable that in the settlement of social conflicts should continue to utilize customary institutions, customary law or local wisdom existing in Indonesia, without ignoring the prevailing laws and regulations, so that the conflicts can be well conceived, wise and prudent.

\section{REFERENCES}

\section{Books}

Lubis, Syahmerdan, Gelar Baginda Raja Muda, Adat Hangoluan Mandailing Tapanuli Selatan, (Medan: CV. Abdi Utama, 2013)
Wijayanti, Asri dan Lilik Sofyan Achmad, Strategi Penulisan Hukum (Bandung: CV. Lubuk Agung, 2011)

\section{Journal Articles}

Aditya, Zaka Firma, 'State Liability for Violation of Constitutional Rights Against Indigenous People in Freedom of Religion and Belief' (2017) 3 (1) Brawijaya Law Journal

Deiredja, Yurika Dibba Destari, Rizky Gelar Pangestu, Hassanain Haykal Haykal, 'Pengembangan Metode Alternatif Penyelesaian Sengketa Bisnis Berdasarkan Kearifan Lokal Melalui Jalur Mediasi' (2013) 2 (2) Zenit

Hamidah, Siti, 'The Analysis of Islamic Economy in The Constitution of indonesia' (2017) 4 (1) Brawijaya Law Journal

Harahap, Anwar Sadat, 'Keberadaan Dalihan na Tolu di Tengah Kehidupan Beragama' (2011) 2 (8) Volume

\section{Jurnal Kalam Keadilan}

Ilyas, 'Kajian Penyelesaian Konflik antar Desa Berbasis Kearifan Lokal di Kabupaten Sigi, Sulawesi Tengah' (2014) 6 (1) Jurnal Academica

Jati, Wasisto Raharjo, 'Kearifan Lokal Sebagai Resolusi Konflik Keagamaan' (2013) 21 (2) Jurnal Walisongo

Kurniawan, Dedi dan Abdul Syani, 'Faktor Penyebab, Dampak dan Strategi Penyelesaian Konflik Antar Warga di Kecamatan Way Panji Kabupaten Lampung Selatan' (2013) 15 (1) Jurnal Sosiologi

Nasution, Adawiyah, 'Penyelesaian Sengketa Pemilihan Kepala Daerah Berbasis Dalihan na Tolu' (2015) 1 (3) Jurnal Kalam Keadilan

Nurcahyo, Abraham, Soebijantoro, Yudi Hartono, 'Model Rekonsiliasi Kultural untuk Mengatasi Konflik Sosial antar 
Perguruan Silat di Madiun' (2014) 6 (2) Sriyanto, Agus, 'Penyelesaian Konflik Jurnal Studi Sosial

Berbasis Budaya Lokal' (2007) 5 (2)

Siregar, Djamaluddin, 'Peranan Adat

Jurnal Ibda

Dalihan na Tolu dalam Pelaksanaan

Kerukunan Umat Beragama pada

Masyarakat Batak' (2014) 3 (6) Jurnal

Kultura 